\title{
Sensitivity and Potential of Terminalia tomentosa Roxb towards Different Gamma Irradiations Exposure Regimes at Early Seedling Growth Phase
}

\author{
S S Singh ${ }^{1}$, Mohd Rafi Wani ${ }^{2}$ \\ School of Natural Resources, Department of Forestry, Wildlife and Environmental Sciences, Guru Ghasidas University, Bilaspur, \\ Chhattisgarh, India, 495009
}

\begin{abstract}
The seeds of Terminalia tomentosa Roxb were collected from Achanakmar Amarkantak Biosphere reserve, Central India. The air dried seeds were exposed to different gamma irradiations doses $(10 \mathrm{kR}, 20 \mathrm{kR}, 40 \mathrm{kR}$ and $60 \mathrm{kR})$ in Continuous (C) and Fractionated $(F)$ pattern using ${ }^{60}$ Co source. The sensitivity and potential of germination, growth and vigor parameters of Terminalia tomentosa under influence of different gamma irradiation doses was examined in the present study. Increase in the germination and growth parameters under the lower continuous and fractionated doses of gamma irradiation indicate the potential of the lower doses of gamma irradiation in the early growth improvement of Terminalia tomentosa. In contrast, the higher doses of gamma irradiation have a retardant effect on germination, growth and vigor parmeters thus the tree show higher sensitivity towards these gamma irradiation doses . It was observed that the fractionated dose pattern cause more inhibition in different germination and growth parameters than the continuous doses. The 10kR continuous dose level showed the best acceptability and maximum enhancement in different growth and germination parameters. The LD-50 values varied among the different growth parameters and it was seen that the leaf formation and radicle were the most sensitive parameter. The PCA indicate and confirm the significance of different continuous and fractionated gamma irradiation doses in altering the germination and early growth parameters of Terminalia tomentosa.
\end{abstract}

Keywords: Gamma irradiation, Continuous and Fractionated doses, Sensitivity and Potential, Germination, Vigor and Terminalia tomentosa

\author{
Abbreviations \\ kR - KiloRad $(1 \mathrm{kR}=10 \mathrm{~Gy})$ \\ C - Continuous \\ F - Fractionated \\ GP - Germination Percentage \\ GV - Germination Value \\ GEI - Germination Energy Index \\ LD-50 - Lethal Dose-50 \\ PCA - Principle Component Analysis
}

\section{Introduction}

New challenges such as climate change, global warming, human population growth, etc., are posing a big threat to the forests of worldwide. Under such conditions forest tree breeders have to look for new innovative tools for tree improvement to develop the tree species with better vigor, growth, establishment, adaptability and resistance against biotic/abiotic environmental stress. The success of any forest tree improvement programme depends upon type and rate of improvement which a forest tree species shows within a specific time. Different methods have been employed for the improvement of different forest tree species but these methods are hindered due to either the biological characteristics of forest trees (long life cycle) or by complex protocols. However in the current era among all the techniques, gamma induced tree improvement is one which has shown a possible gain in the different germination and growth attributes of forest tree species within less time.

Gamma rays belong to ionizing radiation and are the most energetic form of such electromagnetic radiation, having the energy level from around 10 kilo electron volts (keV) to several hundred $\mathrm{keV}$. Therefore, they have more penetrating power than other types of radiation such as alpha and beta rays (Kovacs \& Keresztes, 2002), this is the most economical and effective feature of gamma rays which has made its wider application in the improvement of forest tree species. The exposure of plants towards gamma irradiations has a significant effect on the growth and development of plants by inducing cytological, biochemical, genetic, physiological and morphogenetic changes in the cells/tissues depending on the levels of irradiation regime (Kim et al., 2004; Wi et al., 2005). In addition gamma irradiation can enhance the production of reproductive structures, germination behavior, higher growth, early maturation, accelerated development and disease resistance in plants (Luckey, 1980,1998, 2003).The biological effect of gamma radiation is mainly due to the formation of free radicals by the hydrolysis of water, which may result in the modulation of an antioxidative system, accumulation of phenolic compounds and chlorophyll pigments (Kovacs and Keresztes, 2002; Kim et al., 2004; Wi et al., 2007; Ashraf, 2009 ). The low doses of gamma radiation may enhance the enzymatic activation and awakening of the young embryo, which results in stimulating the rate of cell division and affects not only germination, but also its vegetative growth (Sjodin 1962).Conversely, Some reports on forest tree species (Gunckel \& Sparrow, 1961; Singh, S S and Sujata 2004, Singh and Vandana 2008 and IkRam et al., 2010) has shown that the higher exposures of gamma rays produce generally negative effects on plant growth and development although the effect of dose rate on growth and development might differs among plant species.

The sensitivity of any plant species depends upon three factors such as dose, type of ionizing radiation and factors affecting the recovery from radiation damage (Sparrow and Woodwell 1962). According to Sparrow et al. (1970),

\section{Volume 6 Issue 1, January 2017




\section{International Journal of Science and Research (IJSR) \\ ISSN (Online): 2319-7064}

Index Copernicus Value (2015): 78.96 | Impact Factor (2015): 6.391

woody species are relatively more sensitive when compared to herbaceous types ,thus It becomes important to define the threshold of high doses, which inhibits the growth and also the low doses which has a stimulatory effects on growth and development of the forest tree species. A radiostimulant low dose is defined as any doses that marks the boundary between positive and negative biological effect (Luckey, 2003) on the trees. This radiostimulatory effects which has been observed in different plant species through the use of low doses of ionizing gamma radiation could be considered an interesting alternative somewhat unexplored in forestry practice. So, the manipulation of these low stimulating doses can improve the various economic traits of forest tree species.

The aim of the present investigation is to evaluate the gamma irradiation doses which will show a potential in the enhancement of germination, growth and vigor of Terminalia tomentosa on one hand and on the other hand we screen out the threshold doses of gamma irradiation from which inhibition of germination, growth and vigor parameters take place. The study can prove valuable in recording the sensitivity status of Terminalia tomentosa against acute exposure of gamma irradiation which will help in formulating the improvement and conservation strategies of this species.

\section{Materials and Methods}

The fully mature seeds were collected from the forests of Achanakmar Amarkantak Biosphere reserve, Central India( Location: $21^{0} 15^{\prime}$ to $22^{\circ} 58^{\prime} \mathrm{N}$ and $81^{\circ} 25^{\prime}$ to $82^{\circ} 5^{\prime} \mathrm{E}$ ). The air dried seeds with a moisture content of $7.660 \pm 0.84 \%$ (ISTA 1991) were subjected to different gamma irradiation doses $(10 \mathrm{kR}, 20 \mathrm{kR}, 40 \mathrm{kR}$ and $60 \mathrm{kR})$ using a $\mathrm{Co}^{60}$ gamma source with strength of $.3712 \mathrm{KGy} / \mathrm{Hr}$ (Gamma Chamber, Department of Chemistry, RTM University, Nagpur, Maharastra, INDIA ). The dose regime selection was based on the previous studies on genus Albizia, Bauhinia and Rubinia (Singh and Sujata 2004, Singh and Vandana 2008) where significant results on different germination and growth attributes were recorded under different gamma irradiation treatments.

The doses were given in two different ways as Continuous treatment and Fractionated treatment. For continuous doses the seeds have been irradiated continuously by giving the desired dose uninterruptedly. For fractionated doses, it was done by fractionating the doses in two equal parts by allowing an interval of 24 hours between two equal doses. In this way we tried to compare the pace of DNA repair mechanism by comparing the different germination and growth attributes under influence of continuous and fractionated pattern of gamma irradiation treatments.

Hundred seeds were used for each dose. Each treatment was replicated four times with 25 seeds in each replicate and the whole experiment was arranged in a Randomized Block Design. Seeds without any treatment were taken as control samples and the results of irradiated seeds were compared with the untreated seeds(Control).The experiment was carried out in polypots to study the germination and early seedling growth. An artificial soil was prepared for the experiment. Sand, clay and FYM (Farm Yard Manure) in a ratio 2:1:1 were used for the experiment.The polypots were filled with this soil and the seeds were sown for germination in the polypots in the same orientation. The chemical properties of the soil used for the experiment is given in the following table;

Table 1: The chemical properties of the soil used for the experiment

\begin{tabular}{|c|l|c|}
\hline S.No & \multicolumn{1}{|c|}{ Nutrient } & Status \\
\hline 01 & $\mathrm{C}(\%)$ & $2.45 \pm 0.11$ \\
\hline 02 & Organic Matter $(\%)$ & $3.67 \pm 0.21$ \\
\hline 03 & $\mathrm{~N}(\%)$ & $0.04 \pm 0.01$ \\
\hline 04 & $\mathrm{C} / \mathrm{N}$ & $59.65 \pm 2.39$ \\
\hline 05 & $\mathrm{EC}(\mathrm{dS} / \mathrm{m})$ & $0.18 \pm 0.032$ \\
\hline 06 & $\mathrm{~K}(\mathrm{mg} / \mathrm{kg})$ & $24.3 \pm 1.22$ \\
\hline 07 & $\mathrm{Ca}(\mathrm{mg} / \mathrm{kg})$ & $32.5 \pm 1.67$ \\
\hline 08 & $\mathrm{Mg}(\mathrm{mg} / \mathrm{kg})$ & $27.0 \pm 2.13$ \\
\hline 09 & $\mathrm{P}(\mathrm{mg} / \mathrm{kg})$ & $10.84 \pm .67$ \\
\hline 10 & $\mathrm{pH}$ & $7.14 \pm 1$ \\
\hline
\end{tabular}

The treated and untreated seeds were soaked in distilled water for 48 hours at room temperature $\left(28^{0} \mathrm{C} \pm 1^{0} \mathrm{C}\right)$. Thereafter, they were washed with distilled water and then sown in polypots in the Forestry Nursery (Department of Forestry Wildlife and Environmental Sciences,Guru Ghasidas Vishwavidyalaya, Bilaspur, Chhattisgarh, India) .Fertilizers were not used and the seedlings were irrigated daily.

Germination was described by the presence of a radicle at least $2 \mathrm{~mm}$ long (Mackay et al., 1995). The germinated seeds were counted daily from the starting of the experiment upto the end of the experiment (30 days after seed sowing) and then the germination percentage was calculated (ISTA 1999) by following formulla.

\section{$\mathrm{GP}=$ Number of seeds geminated upto $\mathrm{n}^{\text {th }}$ day $\mathrm{X} 100$ Total number of seeds kept for gemination}

Germination energy index (GEI) was calculated from daily germination record. For germination energy index an appropriate record of newly germinated seeds was made and GEI was calculated by following equation;

$$
\text { GEI }=\frac{A_{1}+\left(A_{2}+A_{2}\right)+\left(A_{1}+A_{2}+A_{3}\right)+\left(A_{1}+A_{2}+A_{3}+\ldots \ldots+A_{2}\right) \times 100}{Y x N}
$$

Where $A_{1}, A_{2}, A_{3}, \ldots \ldots . A_{n}$ is the number of seeds newly germinated on $1,2,3 \ldots$ and $n^{\text {th }}$ days, respectively. $\mathrm{N}$ is the total number seeds used for the treatment, $\mathrm{Y}$ represents the number of days for each observation.

For germination value $(\mathrm{GV})$ germination data were considered upto the day when germination became constant for three consecutive days (peak value). The same day was used as a reference point for computing the germination value and was calculated by following equation (Czabator 1962).

\section{G.V. = MDG X PV}

Where MDG is mean daily germination and PV is the peak value.

\section{Volume 6 Issue 1, January 2017 www.ijsr.net}




\section{International Journal of Science and Research (IJSR) \\ ISSN (Online): 2319-7064}

Index Copernicus Value (2015): 78.96 | Impact Factor (2015): 6.391

The germination speed (S) was determined by using the following equation (Chiapuso et al., 1997).

$\mathrm{S}=\left(\mathrm{N}_{1} \times 1\right)+\left(\mathrm{N}_{2}-\mathrm{N}_{1}\right) \times 1 / 2+\left(\mathrm{N}_{3}-\mathrm{N}_{2}\right) \times 1 / 3$. $+\left(\mathrm{N}_{\mathrm{n}}\right.$

$\left.-\mathrm{N}_{\mathrm{n}-1}\right) \times 1 / \mathrm{n}$

Where $\mathrm{N} 1, \mathrm{~N} 2, \mathrm{~N} 3 \ldots \ldots \ldots \mathrm{Nn}-1, \mathrm{Nn}=$ Proportion of germinated seeds observed at $1,2, \ldots \ldots$ upto $\mathrm{n}^{-1} 1$ and $\mathrm{nth}$ day.

Vigor index was calculated by using the following equation; $\mathrm{V}=\% \mathrm{G} \times(\mathrm{ASL}+\mathrm{ARL})$

Where $\mathrm{V}=$ Vigor index, $\% \mathrm{G}=$ germination percentage, $\mathrm{ASL}=$ Average shoot length, and ARL = Average root length.

Shoot length, radicle length, hypocotyl length and average leaf area were measured on the final day of germination studies. The relative growth rate of the plants where determined in terms of their fresh and dry weight. The dry weight was calculated by keeping the seedlings in an oven at $80^{\circ} \mathrm{C}$ for 24 hours.

LD-50 was calculated for different growth parameters to record the gamma irradiation dose which was found $50 \%$ lethal for the specific parameter and finally a radiosensitive spectrum was prepared on the basis of LD-50 values of each growth parameter.

To determine the level of significance the data were also subjected to multivariate analysis consisting of the principal component analysis. The principal component analysis (PCA) was used to explain the pattern of character covariation among the different gamma irradiation doses.PCA identify the gamma irradiation doses which contribute most to the variation across different doses of gamma irradiations.PCA was calculated by Multibase-2015 support Excel.

The data was subjected to analyses of variance (ANOVA) in a randomized block design. The treatment means were compared using the Duncan Multiple Range Test (Duncan, $1955)$ at $(P \leq 0.05)$ level of significance.

\section{Result and Discussion}

\subsection{Effect of gamma radiation on germination behavior}

The effect of different gamma irradiation doses on germination is given in Fig 1 \& Fig 2. Enhancement in the GP, GV and GEI was recorded under 10kR and 20kR (both Continuous and Fractionated doses) compared to their respective control. Maximum germination percentage (52\% under $10 \mathrm{kRC})$, germination value (27.1\% under $10 \mathrm{kRC})$ and germination energy index (9.28 under 20kRC) was recorded than the control $(\mathrm{GP}=37 \%, \mathrm{GV}=15.73$ and $\mathrm{GEI}=4.26)$ respectively. The lower continuous doses showed much potential in the enhancement of these germination parameters than the fractionated doses. The potential of lower doses in the improvement in germination percentage was also recorded in Tectona grandis (Bhargava and Khalatkar, 1987), Hyoscyamus muticus (Abo and Omran, 1976), and Pterocarpus santalinus (Akshatha, 2013). The stimulatory effect of lower doses of gamma irradiation on the germination may be due to the activation of RNA synthesis or protein synthesis (Kuzin et al., 1976) during early stage of germination of treated seeds. The enhancement of germination in lower doses of gamma irradiations may be due its effect on $\mathrm{N}$ products, as $\mathrm{N}$ products can enhance seed germination by adjusting $\mathrm{K}+/ \mathrm{Na}+$ ratio and increasing ATP production and seed respiration (Zhang et al., 2009).More over the lower doses of gamma irradiations may enhance the enzymatic activation and awakening of young embryo which results in stimulating the rate of cell division and hence enhancement of germination occur. The poor germination and early seedling establishment being one of the central problem in the conventional breeding of this forest tree species. Thus the potential of the lower doses of gamma irradiations can be exploited for the germination improvement and seeding establishment of Terminalia tomentosa as specific, and in general for other forest tree species.

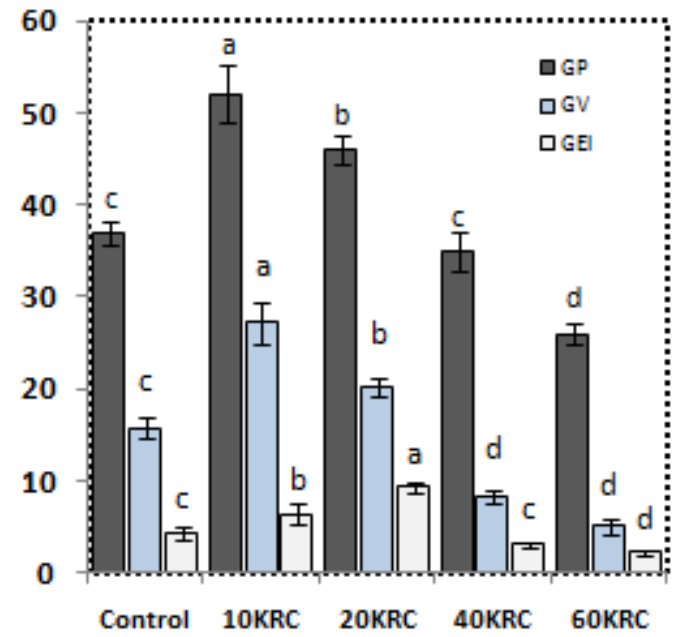

Figurel

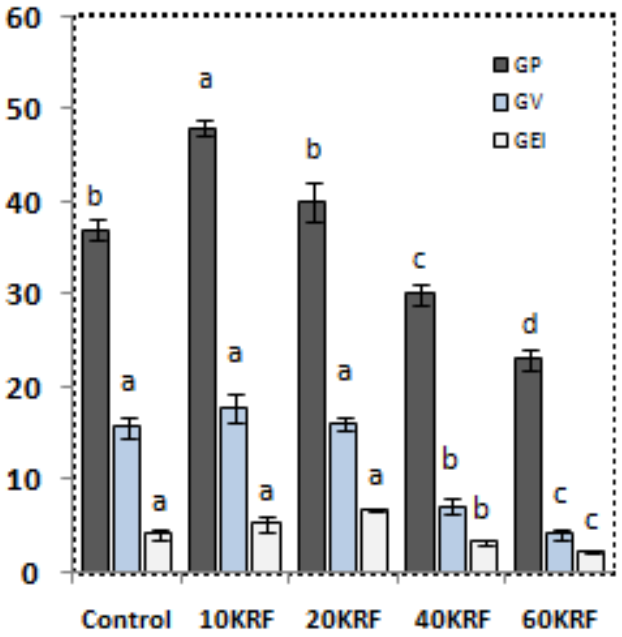

Figure 2

Terminalia tomentosa- Effect of different continuous doses (Fig-1) and Fractionated doses (Fig-2) of gamma irradiation on germination percentage (GP), germination value $(\mathrm{GV})$ and germination energy index (GEI). Bars showing the same letter are not significantly different at $P \leq 0.05$. The data shown are mean \pm SE of four replicates.

Volume 6 Issue 1, January 2017

www.ijsr.net

Licensed Under Creative Commons Attribution CC BY 


\section{International Journal of Science and Research (IJSR) \\ ISSN (Online): 2319-7064}

Index Copernicus Value (2015): 78.96 | Impact Factor (2015): 6.391

The higher doses (except 10kR C\&F) and 20kR C\&F) cause reduction in these parameters. The inhibition of the seeds to germinate at higher doses of gamma irradiation can be attributed to several reasons like a) Histological and cytological changes (Kiong et al., 2008, Sax,1942) b) disruption and disorganization of the tunica or seed layer which is directly proportional to the intensity of exposure of gamma irradiations c) impaired mitosis in the meristematic zones during germination (Lokesha et al. 1992). The results were in accordance with the earlier reports on Acacia leucophloea (Selvaraju et al., 2001). A significant statistical variation exists ( at $\alpha=0.05 \%$ level of significance) between the values obtained for the germination percent $(p=0.017)$, germination value $(p=0.001)$ and germination energy index $(p=0.024)$ under the influence of different continuous and fractionated doses of gamma irradiations and the control (Fig 1\& 2).

\subsection{Effect of gamma irradiation on speed of germination of Termnalia tomentosa}

The effect of the different continuous and fractionated doses of gamma irradiation on the germination speed of Terminalia tomentosa is shown in Figure 3. A two-fold higher speed of germination was recorded from the seeds irradiated with $10 \mathrm{kRF}(3.15 \pm 0.35)$ than the control $(1.23 \pm 0.17)$. The higher continuous cause reduction in the speed of germination. However all the fractionated doses except $60 \mathrm{kRF}$ increased the speed of germination than the control. .Maximum speed of germination was recorded in the seedlings of the seeds irradiated with $10 \mathrm{kRF}$ followed by $10 \mathrm{kRC}, 40 \mathrm{kRF}, 20 \mathrm{kRF}, 20 \mathrm{kRC}$, Control, 40kRC, 60kRF and $60 \mathrm{kRC}$ respectively. The increase in the speed of germination in Terminalia tomentosa under the low doses of gamma irradiation might be due to the stimulating effects on hormesis (Sparrow 1960 and Thapa 1999), RNA synthesis or protein synthesis as reported by Kuzin at al., (1976). More over the low fractionated doses of gamma radiation may increase the enzymatic activation and awakening of the young embryo than the continuous doses, which results in stimulating the rate of cell division and thus enhancement of the germination speed. It has been observed that the speed of germination in Terminalia arjuna was higher than the control and was maximum in the seeds irradiated with 100 Gy followed by the plants of seeds irradiated with 25, 50, 200, and 150 Gy, respectively (Akshatha et al., 2014).

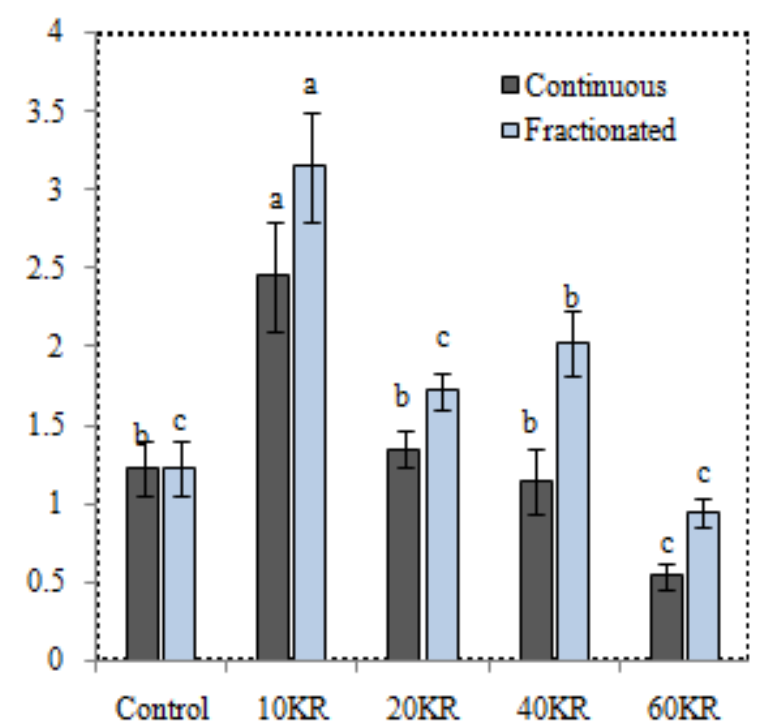

Figure 3: Terminalia tomentosa- Effect of Continuous and Fractionated doses of gamma irradiation on germination speed (GS). Bars showing the same letter are not significantly different at $P \leq 0.05$. The data shown are mean $\pm \mathrm{SE}$ of four replicates.

\subsection{Effect of gamma irradiation on vigor index of Termnalia tomentosa}

The vigor index is a product total plant length and germination percentage shown in Figure 4. The vigor index shows the overall efficiency of the plants in terms of growth and germination. A significant variation between the vigor index values of seedlings grown was recorded $(p=0.017)$ at $0.05 \%$ of probability under different gamma irradiation treatments of the seedlings. The highest vigor index (1565.2) was recorded under $10 \mathrm{kRC}$ treated plants, followed by $10 \mathrm{kRF}, 20 \mathrm{kRF}, 20 \mathrm{kRC}$, Control, 40kRF, 40kRC, 60kRF and $60 \mathrm{kRC}$ respectively. The four gamma irradiation doses $10 \mathrm{kR}(\mathrm{C} \& \mathrm{~F})$ and $20 \mathrm{kR}(\mathrm{C} \& \mathrm{~F})$ potentially increased the vigor of the seedlings from germination to their vegetative growth than the untreated seedlings (control). There are many possible reasons for the stimulation in the vigor index of the seedlings under lower continuous and fractionated gamma irradiation doses. The enhancement in the vigor index could be due to the stimulatory effect of lower gamma irradiation doses along with their adaptive resistance to the radiation stress.It also effects enzyme activity since higher seedling vigor is associated to germination efficiency.It has been reported that high $\alpha$-amylase activity increase metabolic activity leading to enhanced seedling vigor.Hence it may be infused that the lower continuous and fractionated gamma irradiation doses enhances the $\alpha$-amylase activity, in contrast the higher continuous and fractionated doses decrease $\alpha$ amylase activity thus inhibition in the seedling vigor (Afzal et.al., 2008; Kumagai et.al., 2000 and Stoeva et al., 2001). The results of the present investigation were in accordance with the reports on in Terminalia arjuna and Pterocarpus santalinus (Akshatha et al., 2014; Akshatha and Chandrashekar, 2013).In Bambusa arundinacea the low doses of gamma irradiation showed an enhancement in the seedling vigor ( Lokesha et.al., 2008) The potential of $10 \mathrm{kRC}$ and $10 \mathrm{kRF}$ gamma irradiation doses in the improvement of vigor index can be exploited and utilized for the developing vigor Terminalia tomentosa stands which can

Volume 6 Issue 1, January 2017

www.ijsr.net

Licensed Under Creative Commons Attribution CC BY 


\section{International Journal of Science and Research (IJSR) \\ ISSN (Online): 2319-7064 \\ Index Copernicus Value (2015): 78.96 | Impact Factor (2015): 6.391}

act in future as a germplasm store for the delivery of different goods and services in a sustainable way. Moreover these lower doses can help in production of the seedlings stock with better establishment, which can be used to supplement the natural regeneration problems of this tree within the forests.

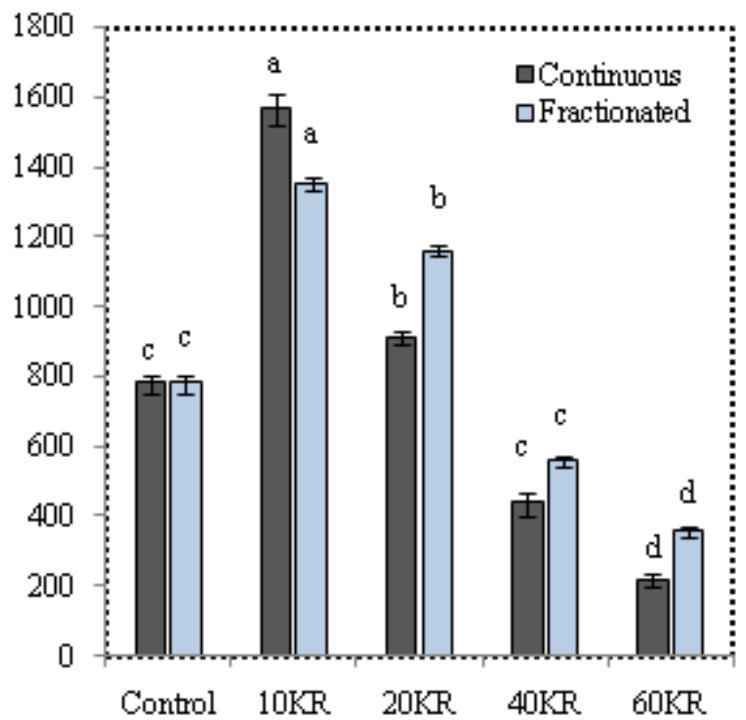

Figure 4: Terminalia tomentosa- Effect of Continuous and Fractionated doses of gamma irradiation on Vigor Index (VI). Bars showing the same letter are not significantly different at $P \leq 0.05$. The data shown are mean $\pm \mathrm{SE}$ of four replicates.

\subsection{Effect of gamma irradiation on fresh weight and dry weight of different growth parameters in Terminalia tomentosa}

The fresh and dry weight of radicle was slightly enhanced by $\quad 10 \mathrm{kRC} \quad(6.49 \pm 0.52 \quad \& \quad 2.39 \pm 0.17) \quad$ and $20 \mathrm{kRC}(05.63 \pm 0.46 \mathrm{~g} \quad \& \quad 1.25 \pm 0.08 \mathrm{~g})$ dose than the control $(4.67 \pm 0.02 \mathrm{~g} \& 0.56 \pm 0.02 \mathrm{~g})$ respectively, while the higher continuous doses cause reduction of these parameters. The lower continuous doses does not show any effect on the fresh and dry weight of hypocotyls, where as the higher continuous reduced these parameters. An irregular trend in the increase of the fresh weight and dry weight of cotyledon was observed under different continuous doses. Highest fresh weight and dry weight was observed under $10 \mathrm{kRC}(10.05 \pm 1.10 \mathrm{~g} \& 03.25 \pm 0.17 \mathrm{~g})$ and $60 \mathrm{kRC}(10.21 \pm 0.28 \mathrm{~g} \& 3.32 \pm 0.09 \mathrm{~g})$ in compare to the fresh and dry weight of untreated seedlings $(08.23 \pm 0.72 \mathrm{~g} \&$ $02.65 \pm 0.04 \mathrm{~g}$ ), while the other doses don't show any significant change.A slight increase in the fresh and dry weight of shoot was observed under $10 \mathrm{kRC}$ and $20 \mathrm{kRC}$ than the control, while other doses cause inhibition of the fresh and dry weight of shoot(Table-2).

Table 2: Terminalia tomentosa - Effect of different Continuous $(\mathrm{C})$ and Fractionated $(\mathrm{F})$ doses of gamma irradiations on fresh weight and dry weight of different growth parameters in Terminalia tomentosa

\begin{tabular}{|r|c|c|c|c|c|c|c|c|}
\hline \multirow{2}{*}{$\begin{array}{c}\text { Dose } \\
\text { Level }\end{array}$} & \multicolumn{2}{|c|}{ Radicle } & \multicolumn{2}{c|}{ Hypocotyl } & \multicolumn{2}{c|}{ Cotyledonary leaves } & \multicolumn{2}{c|}{ Shoot } \\
\cline { 2 - 9 } & FW & DW & FW & DW & FW & DW & FW & DW \\
\hline Control & $4.67 \pm 0.02$ & $0.56 \pm 0.02$ & $02.18 \pm .02$ & $0.36 \pm 0.03$ & $08.23 \pm 0.72$ & $02.65 \pm 0.04$ & $07.16 \pm 0.24$ & $02.16 \pm 0.09$ \\
\hline $10 \mathrm{kR}-\mathrm{C}$ & $6.49 \pm 0.52$ & $2.39 \pm 0.17$ & $02.10 \pm 1.12$ & $0.34 \pm 0.05$ & $10.05 \pm 1.10$ & $03.25 \pm 0.17$ & $09.32 \pm 0.32$ & $03.36 \pm 0.07$ \\
$-\mathrm{F}$ & $5.14 \pm 0.45$ & $2.84 \pm 0.07$ & $02.32 \pm 0.45$ & $0.47 \pm 0.07$ & $07.45 \pm 0.95$ & $2.75 \pm 0.12$ & $10.85 \pm 1.17$ & $03.78 \pm 0.72$ \\
\hline $20 \mathrm{kR}-\mathrm{C}$ & $05.63 \pm 0.46$ & $1.25 \pm 0.08$ & $02.00 \pm 0.61$ & $0.25 \pm 0.01$ & $08.19 \pm 0.64$ & $02.16 \pm 0.04$ & $08.68 \pm 0.21$ & $02.18 \pm 0.01$ \\
$-\mathrm{F}$ & $06.32 \pm 0.37$ & $2.21 \pm 0.05$ & $03.39 . \pm 0.24$ & $1.22 \pm 0.02$ & $06.13 \pm 0.74$ & $2.19 \pm 0.09$ & $12.57 \pm 0.98$ & $04.25 \pm 0.19$ \\
\hline $40 \mathrm{kR}-\mathrm{C}$ & $3.09 \pm 0.16$ & $0.72 \pm 0.06$ & $01.96 \pm 0.02$ & $0.18 \pm 0.02$ & $07.16 \pm 0.57$ & $02.45 \pm 0.09$ & $06.27 \pm 0.42$ & $01.76 \pm .0 .04$ \\
$-\mathrm{F}$ & $4.15 \pm 0.10$ & $1.97 \pm 0.06$ & $02.10 \pm 0.09$ & $0.32 \pm 0.02$ & $08.68 \pm 0.84$ & $02.95 \pm 0.11$ & $09.15 \pm 0.64$ & $03.17 \pm .0 .13$ \\
\hline $60 \mathrm{kR}-\mathrm{C}$ & $02.12 \pm 0.09$ & $0.46 \pm 0.07$ & $1.73 \pm 0.03$ & $0.18 \pm 0.02$ & $10.21 \pm 0.28$ & $3.32 \pm 0.09$ & $05.32 \pm 0.09$ & $1.57 \pm 0.03$ \\
$-\mathrm{F}$ & $03.28 \pm 0.14$ & $1.36 \pm 0.02$ & $01.84 \pm 0.06$ & $0.18 \pm 0.07$ & $09.69 \pm 0.96$ & $3.20 \pm 0.27$ & $06.09 \pm 0.36$ & $2.38 \pm 0.09$ \\
\hline
\end{tabular}

The data shown are mean \pm SE of five replicates.

$10 \mathrm{kRF}$ and 20kRF gamma irradiation doses increased the fresh weight of the radicle than the control, where as the other doses don't show any significant change in the fresh weight of the radicle (Table-2). All the fractionated doses increased the dry weight of the radicle than the control and the highest dry weight of radicle was observed in $10 \mathrm{kRF}(2.84 \pm 0.07 \mathrm{~g})$ than the control $(0.56 \pm 0.04 \mathrm{~g})$. An enhancement in the fresh and dry weight of the hypocotyl was recorded under $20 \mathrm{kRF}(03.39 . \pm 0.24 \& 1.22 \pm 0.02 \mathrm{~g})$ than the control $(02.18 \pm 0.02 \& 0.36 \pm 0.03 \mathrm{~g})$, the other fractionated doses doesn't show any significant change than the control except $60 \mathrm{kRF}$ which reduced the fresh and dry weight of the hypocotyl. All the fractionated doses increased the fresh and dry weight of the shoot than the control ,except 60kRF which don't show any significant change than the control.
Khodary and Moussa (2003) confirmed these results that radiation of $20 \mathrm{~Gy}$ on dry seeds improves total chlorophyll content, which increases chlorophyll activity and thus accumulates more biomass. In contrast the higher dose of gamma rays up to 500 Gy decreases chlorophyll content by $80.91 \%$ and decreases the organized pattern of grana and stroma thylakoid (Alikamanoglu et al. 2011) thus inhibiting the rate of phosynthesis (carbon fixation) results in the reduction of the biomass. Our findings were in the same direction for Albizia, Bauhinia and Rubinia (Singh, S S and Sujata 2004, Singh and Vandana 2008) respectively. The enhancement in the fresh and dry weight under the different continuous and fractionated doses of gamma irradiations in different parts of the Terminalia tomentosa seedling indicates the enhancement in the rate of carbon fixation by the treated seedlings. This potential of carbon sequestration by the treated seedlings can be considered in the current era of global warming and option for its mitigation.

\section{Volume 6 Issue 1, January 2017 www.ijsr.net}




\section{International Journal of Science and Research (IJSR) \\ ISSN (Online): 2319-7064 \\ Index Copernicus Value (2015): 78.96 | Impact Factor (2015): 6.391}

3.5 Effect of gamma irradiation on growth pattern in Termnalia tomentosa

There was no significant difference in the shoot length, hypocotyls length, radicle length, average leaf area and number of leaves between the lower continuous gamma irradiation treatments and the control (Table-3). However the gamma irradiation treatments above $20 \mathrm{kRC}$ reduced these parameters as compared to the control. The reduction in the shoot length and root length above the $20 \mathrm{kRC}$ gamma irradiation treatments clarify the sensitivity of shoot length towards gamma irradiations. A decrease in shoot length with increased doses of radiation in A. hirsutus, G. xanthochymus and $S$. asoca was also observed (Akshatha and Chandrashekar, 2014). It was observed that increased dose of gamma irradiation reduced shoot and root length in two species of Pinus (Thapa,2004).The reduction in the root and shoot length by higher continuous gamma radiation doses may be attributed to the reduction of mitotic activity of the cells (Khalil et al. 1986). At the high gamma irradiation exposure the cells which have more chromosomnal damage are at a disadvantage due to diplontic selection and cannot compete well with the normal cells thus prevent from making further contribution for growth (Shah et al, 2008).Preussa and Britta (2003) stated that a high dose of gamma radiations contributes in cell cycle arrest during $\mathrm{G} 2 / \mathrm{M}$ phase, inhibiting growth during cell division. In the present study it was observed that Terminalia tomentosa showed a radioresistance in terms of root and shoot growth to the lower continuous doses of gamma irradiation.

Table 3: Effect of different Continuous(C) and Fractionated(F) doses of gamma irradiation on the growth parameters of Terminalia tomentosa

\begin{tabular}{|c|c|c|c|c|c|}
\hline Dose Level & $\begin{array}{c}\text { Radicle length } \\
(\mathrm{mm})\end{array}$ & $\begin{array}{c}\text { Hypocotyl length } \\
(\mathrm{mm})\end{array}$ & $\begin{array}{c}\text { Shoot length } \\
(\mathrm{cm})\end{array}$ & $\begin{array}{c}\text { Avg. no. of } \\
\text { leaves }\end{array}$ & $\begin{array}{c}\text { Average Leaf } \\
\text { Area }\left(\mathrm{cm}^{2}\right)\end{array}$ \\
\hline Control & $16.6 \pm 1.50^{\mathrm{a}}$ & $03.4 \pm 1.17^{\mathrm{a}}$ & $13.5 \pm 1.51^{\mathrm{a}}$ & $09 \pm 1.21^{\mathrm{b}}$ & $12.5 \pm 0.32^{\mathrm{a}}$ \\
\hline $10 \mathrm{kR}-\mathrm{C}$ & $18.2 \pm 2.60^{\mathrm{a}}$ & $03.7 \pm 0.32^{\mathrm{a}}$ & $15.2 \pm 2.40^{\mathrm{a}}$ & $11 \pm 2.84^{\mathrm{a}}$ & $11.2 \pm 0.21^{\mathrm{a}}$ \\
\hline$-\mathrm{F}$ & $19.3 \pm 2.43^{\mathrm{ab}}$ & $04.2 \pm 0.17^{\mathrm{NS}}$ & $16.3 \pm 2.40^{\mathrm{b}}$ & $13 \pm 0.90^{\mathrm{a}}$ & $15.0 \pm 1.44^{\mathrm{b}}$ \\
\hline $20 \mathrm{kR}-\mathrm{C}$ & $13.5 \pm 1.21^{\mathrm{b}}$ & $03.02 \pm 0.67^{\mathrm{a}}$ & $10.5 \pm 1.21^{\mathrm{b}}$ & $07 \pm 1.66^{\mathrm{c}}$ & $09.6 \pm 0.65^{\mathrm{b}}$ \\
\hline$-\mathrm{F}$ & $21.5 \pm 1.21^{\mathrm{a}}$ & $05.62 \pm 0.35^{\mathrm{NS}}$ & $19.5 \pm 1.21^{\mathrm{a}}$ & $11 \pm 3.21^{\mathrm{a}}$ & $18.7 \pm 2.37^{\mathrm{a}}$ \\
\hline $40 \mathrm{kR}-\mathrm{C}$ & $08.6 \pm 0.56^{\mathrm{c}}$ & $02.20 \pm 0.52^{\mathrm{a}}$ & $08.0 \pm 0.89^{\mathrm{b}}$ & $04 \pm 2.21^{\mathrm{d}}$ & $07.1 \pm 0.54^{\mathrm{c}}$ \\
$-\mathrm{F}$ & $12.2 \pm 0.89^{\mathrm{b}}$ & $03.57 \pm 0.14^{\mathrm{NS}}$ & $12.2 \pm 0.89^{\mathrm{b}}$ & $06 \pm 1.54^{\mathrm{c}}$ & $09.0 \pm 1.22^{\mathrm{d}}$ \\
\hline $60 \mathrm{kR}-\mathrm{C}$ & $07.2 \pm 0.63^{\mathrm{c}}$ & $01.50 \pm 0.10^{\mathrm{b}}$ & $05.2 \pm 1.66^{\mathrm{c}}$ & $03 \pm 0.94^{\mathrm{e}}$ & $04.5 \pm 0.14^{\mathrm{d}}$ \\
$-\mathrm{F}$ & $07.6 \pm 1.66^{\mathrm{c}}$ & $02.35 \pm 0.07^{\mathrm{NS}}$ & $06.8 \pm 1.66^{\mathrm{c}}$ & $04 \pm 1.66^{\mathrm{d}}$ & $07.5 \pm 1.04^{\mathrm{d}}$ \\
\hline
\end{tabular}

The data shown are mean \pm SE of five replicates.Means within a column followed by same letter are not significantly different $(P \leq 0.05)$,NS: Not significant, Different letters a, b, $\mathrm{c}$ and $\mathrm{d}$ denote significant difference $(P \leq 0.05)$ between different treatments

The significant effect on the different growth parameters was observed under the fractionated doses of gamma irradiations (Table-3) as compared to the control seedlings. Since the lower continuous doses were found to be radioresistant and higher continuous doses were recorded as radio-sensitive, but a potential increase in the shoot and root length, number of leaves and average leaf area was recorded in the seedlings under lower fractionated gamma irradiation treatments. A max increase in the shoot length was seen under $20 \mathrm{kRF}(19.5 \pm 1.21)$, followed by $10 \mathrm{kRF}(16.3 \pm 2.43)$ than the control $(13.5 \pm 1.50)$ respectively.Toker et al.'s (2005) findings show that radiations up to $200 \mathrm{~Gy}$ increase shoot length, but further increase to 400 Gy causes reduction in the shoot length. Likewise the enhancement of the radicle length was observed (Table-4).However 60kRF inhibited these parameters. Melki and Marouani's (2010) research concluded that a low dose of 20 Gy gamma radiations enhances the root length and number by $18-32 \%$. Highest number of leaves was seen under 10kRF $(16 \pm 0.90)$ and highest average leaf area was recorded under $20 \mathrm{kRF}$ dose $\left(18.7 \pm 1.37 \mathrm{~cm}^{2}\right)$ than the control respectively (Table-4). The increase in the number of leaves formed may be due to the enhancement in the production of growth hormone kinetin which is responsible for the production of large number of leaves and branches (Minisi et al. 2013). These results indicate the significance of fractionated doses over continuous gamma irradiation doses in the vegetative growth of Terminalia tomentosa. The ability of repair system of a plant to overcome the damaging effect of different gamma irradiation dose increases its radioresistance but if the biological material will be irradiated after specific intervals (Fractionated dose) the chance of its repair system decreases hence possibility in the modification of important components of the cell increase, which effects differentially on the morphology, anatomy, biochemistry and physiology of plants. These effects include changes in the plant cellular structure and metabolism e.g., dilation of thylakoid membranes, alteration in photosynthesis, modulation of oxidative system and accumulation of phenolic compounds (Kim et al., 2004; Wi et al., 2005). This can be a reason for the enhancement of different growth parameters ( Table-3) under fractionated gamma irradiation doses.

\subsection{Sensitivity of different growth parameters by LD-50 values in Terminalia tomentosa}

The LD-50 was calculated for different growth parameters of Terminalia tomentosa towards the different gamma irradiation treatments to observe the radiosensitivity of these growth parameters. The LD-50 values varied among the different growth parameters and it was seen that the leaf formation and radicle were the most sensitive parameter (Fig 5. A, B, C,D, E and F). The LD-50 value for the radicle length were $41 \mathrm{KRC} \& 56 \mathrm{KRF}$ and for the average leaf formation it was $36 \mathrm{KRC} \& 54 \mathrm{KRF}$ respectively (Fig 5 : A, $\mathrm{B}, \mathrm{C} \& \mathrm{D})$ ).The LD-50 value recorded for the shoot growth was $42 \mathrm{KRC} \& 56 \mathrm{KRF}$.The LD-50 values for different parameters showed a marked variation which clearly indicates the difference in the interaction of the gamma irradiations and the seedling tissues. 


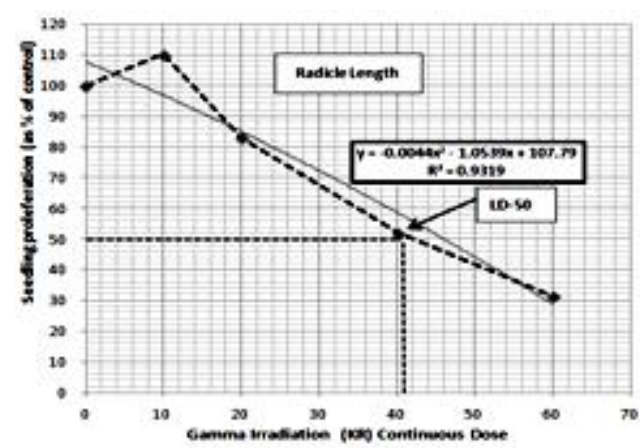

A

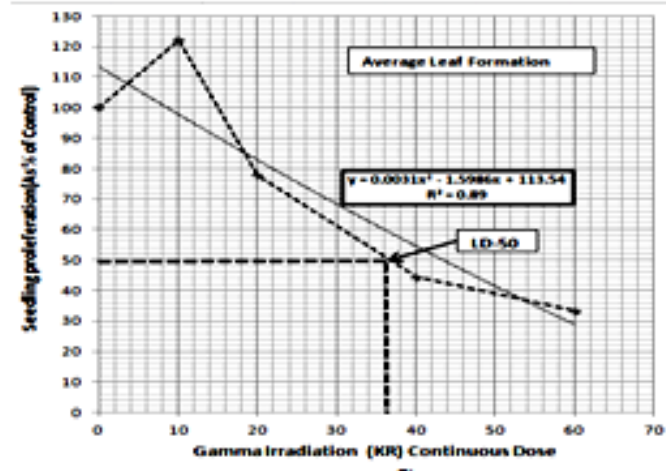

C.

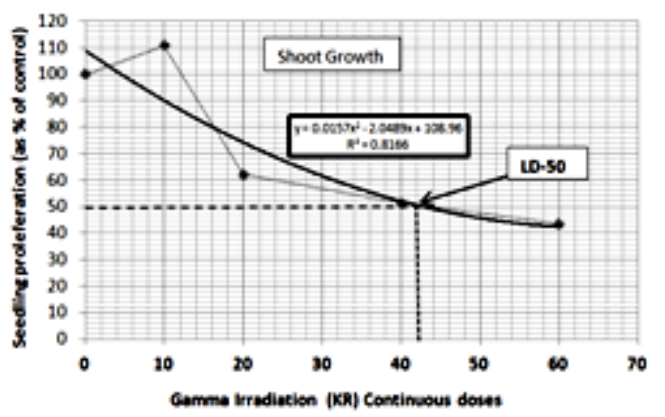

$\mathrm{E}$

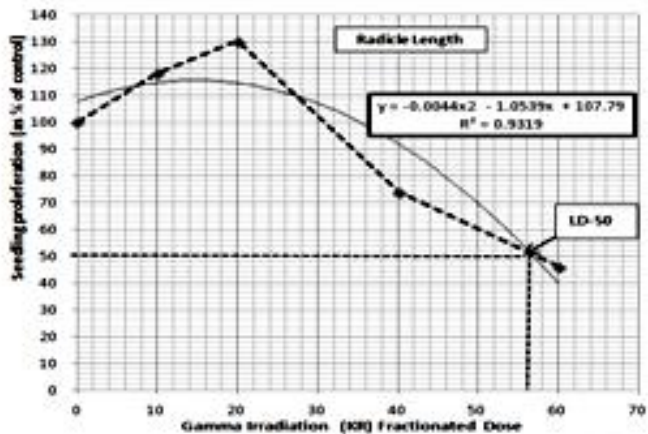

B

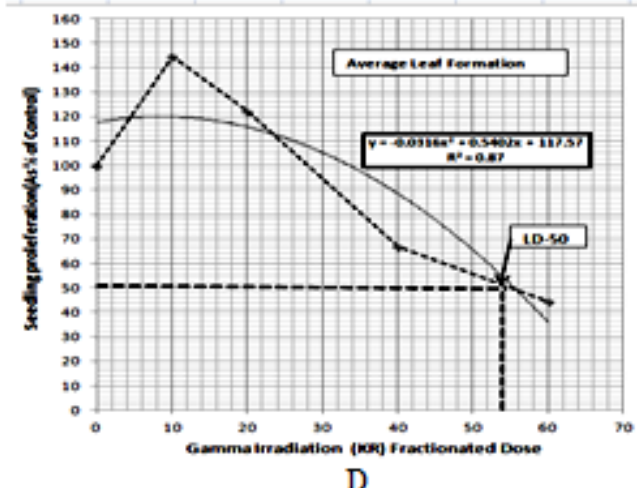

D

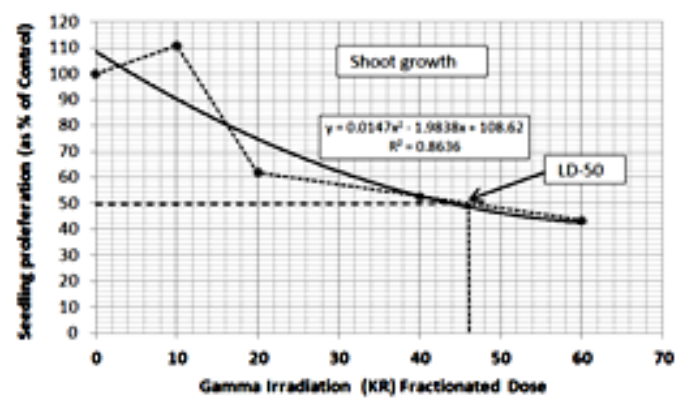

$\mathrm{F}$

Figure 5: A, B, C,D, E and F: LD-50 values for Radicle, average leaf formation and shoot growth under continuous and fractionated gamma irradiation doses in Terminalia tomentosa

The LD-50 values can be utilized for the trait bases improvement of Terminalia tomentosa. A radiosensitive spectrum was prepared for the different growth parameters on the basis of their LD-50 values, which is represented according to their sensitivity as;

\section{Leaf formation $>$ Radicle $>$ Shoot growth}

Vanhoudt et al. (2014) demonstrated the role of ROSscavenging enzymes, SOD, CAT, ascorbate, peroxidase (APX), guaiacol peroxidase (GPX), and syringaldazine peroxidase (SPX) in roots and leaves of A. thaliana and reported that enzyme capacity gets affected in roots/leaves making them more radiosensitive than other parameters. The global context of climate change and the electromagnetic pollution to which the forest trees are exposed in the current era, an elite strategy can be developed for the conservation, management and improvement of Terminalia tomentosa from the present work. Moreover gamma irradiations can help to develop radiosensitive models for different tissues and forest tree species by which we can monitor the most sensitive tree species which require an ultimate conservation.

\subsection{Principle component analysis}

The extent of variation caused by the different gamma irradiation doses on different germination and early growth parameters of Terminalia tomentosa was assessed by multivariate technique. Principal Component Analysis (PCA) was performed for different germination and early growth parameters of Terminalia tomentosa under influence of different doses of gamma irradiations. The result of combined PCA across different gamma irradiation doses are presented in Table-4.

\section{Volume 6 Issue 1, January 2017 www.ijsr.net}




\section{International Journal of Science and Research (IJSR) \\ ISSN (Online): 2319-7064}

Index Copernicus Value (2015): 78.96 | Impact Factor (2015): 6.391

Table 4: Eigen values, percent of total variation accounted for, cumulative percent and eigen vectors of germination and early growth parameters (Terminalia tomentosa) of the first

four principal components under influence of different gamma irradiation doses

\begin{tabular}{|c|c|c|c|c|}
\hline Dose & Comp 1 & Comp 2 & Comp 3 & Comp 4 \\
\hline Control & -0.02 & -0.09 & -0.35 & -0.68 \\
\hline 10kRC & -3.23 & $\mathbf{0 . 4 9}$ & $\mathbf{0 . 6 8}$ & -0.62 \\
\hline 20kRC & -1.21 & $\mathbf{2 . 0 8}$ & -0.48 & $\mathbf{0 . 3 9}$ \\
\hline 40kRC & $\mathbf{1 . 7 5}$ & $\mathbf{0 . 3 8}$ & $\mathbf{0 . 6 5}$ & $\mathbf{0 . 4 1}$ \\
\hline 60kRC & $\mathbf{3 . 5 8}$ & $\mathbf{0 . 7 7}$ & -0.04 & -0.04 \\
\hline 10kRF & $\mathbf{2 . 6 5}$ & -0.78 & $\mathbf{0 . 9 8}$ & $\mathbf{0 . 3 3}$ \\
\hline 20kRF & -2.15 & -0.91 & -1.54 & $\mathbf{0 . 4 3}$ \\
\hline 40kRF & $\mathbf{1 . 0 5}$ & -1.16 & $\mathbf{0 . 2 1}$ & $\mathbf{0 . 3 9}$ \\
\hline 60kRF & $\mathbf{2 . 8 8}$ & -0.68 & -0.11 & -0.40 \\
\hline Eigenvalue & $\mathbf{6 . 8 7}$ & $\mathbf{1 . 1 9}$ & $\mathbf{0 . 6 5}$ & $\mathbf{0 . 2 3}$ \\
\hline
\end{tabular}

A common rule of thumb for determining the significance of a dose coefficient is to treat coefficient greater than 0.3 as having a large enough effect to be considered important under PCA analysis. The gamma irradiation doses having less than 0.2 coefficient value were considered to have less contribution to the over-all variation observed in the present study.

The results from the PCA revealed that only two of the principal components had eigen values greater than 1.0. The first two axes with Eigen values of 6.87 and 1.19 respectively, jointly accounted for $89.5 \%$ of the total variation in response to the gamma irradiation dose. The first PC accounted for $76.3 \%$ of the variability which was related to the different germination and growth parameters of Terminalia tomentosa. Thus the information contained in the different germination and early growth parameters measured under different doses can be explained satisfactorily based on the analysis of the frist two PCA components, as if the number of a component that explain 0$90 \%$ of total variance must be considered (Ferreira 2008).The 60kRC,60kRF,40kRF,40kRC and 20kRC were the highest contributors for variation to the first and second component.

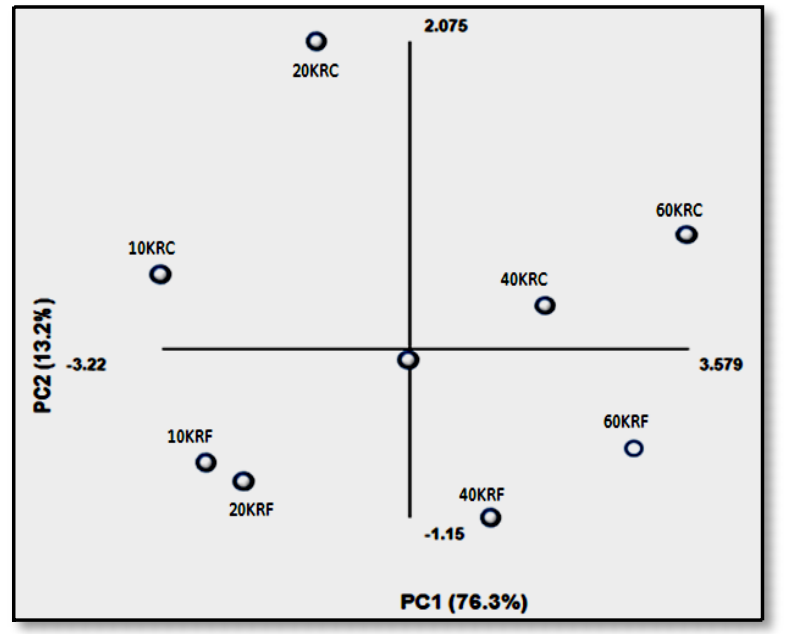

Figure 6: Biplot of the first and second principal components to show the interrelationship of different gamma irradiation doses on germination and early growth parameters of Terminalia tomentosa .
A further understanding was obtained by plotting the PC scores for individual observations in relation to the axes of PC1 and PC2 (Fig 6). The figure clearly describes a same type of response of the doses $10 \mathrm{kRF}$ and $20 \mathrm{kRF}$ on the different germination and growth parameters of Terminalia tomentosa as they were found much closer to each other than the other doses. However the effect of the other doses was dose dependent. The doses 10kRC and 60kRF show the highest separate dose response to the different germination and growth parameters respectively. This contribution in variation of the different gamma irradiation doses indicate their significance in altering the germination and early growth parameters of Terminalia tomentosa. However the positive and the negative effects by continuous and fractionated gamma irradiation doses can be screened out to describe the radiopotential and radiosensitivity of Terminlalia tomentosa and the future implication of radiopotential doses in the forest tree improvement programmes.

\section{Conclusion}

Nuclear techniques have broadened the scope of forest tree improvement and genetics. The lower doses of gamma irradiation treatments have a potential to enhance the different germination and growth parameter of Terminalia tomentosa. This potential of gamma irradiations can help in the improvement of the regeneration and seedling establishment of this species for the development of better Terminalia tomentosa stands. On the other side the higher doses were found to be sensitive for Terminalia tomentosa germination and growth. These sensitive doses can be screened and the establishment of prior conservation strategies of this species can be lay-out in the current era of climate change. The gamma irradiations can be used to establish safety criteria for nuclear facilities and its peaceful application in forestry. The present investigation was restricted to only the early growth phases, however a further work on the monitoring of this species for the different growth and reproductive end point is in progress.

\section{Conflict of Interest}

The authors declare that they do not have any conflict of interest

\section{Acknowledgments}

Authors are thankful to RTM Nagpur University (Department of Chemistry) for providing irradiation facility.

\section{References}

[1] Abo Elsauod I A, Omran A F (1976) Effect of gamma radiation on growth and respiration of snap beans. Hort Abst. 46: 947.

[2] Afzal, Shah T M , Atta B M , Haq M A and Sayed H (2008) Gamma irradiation effects on seed germination and growth, protein content, peroxidase and protease activity, lipid peroxidation in desi and kabuli chickpea. Pakistan Journal of Botany. 40:1033-1041. 


\section{International Journal of Science and Research (IJSR) \\ ISSN (Online): 2319-7064}

Index Copernicus Value (2015): 78.96 | Impact Factor (2015): 6.391

[3] Akshatha Chandrashekar K R, Somashekarappa H M, Souframanien J (2014) Effect of gamma irradiation on germination, growth, and biochemical parameters of Terminalia arjuna Roxb. Radiat. Prot. Environ. 36 (1): 38-44.

[4] Ahloowalia B S and Maluszynski M (2001) Induced mutations-A new paradigm in plant breeding. Euphytica. 118: 167-73.

[5] Akshatha Chandrashekar K R (2013) Effect of gamma irradiation on germination growth and biochemical parameters of Pterocarpus santalinus, an endangered species of Eastern Ghats. Eur. J. Exp. Biol. 3 (2): 266270.

[6] Akshatha Chandrashekar K R (2014) Gamma sensitivity of forest plants of Western Ghats. Journal of Environmental Radioactivity. 132: 100-107.

[7] Alikamanoglu S, Yaycili O and Sen A (2011) Effect of gamma radiation on growth factors, biochemical parameters, and accumulation of trace elements in soybean plants (Glycine max L. Merrill). Biol Trace Elem Res. 141(1-3):283-293

[8] Ashraf M (2009) Biotechnological approach of improving plant salt tolerance using antioxidants as markers. Biotechnol Adv. 27: 84-93.

[9] Bhargava Y R and Khalatkar A S (1987) Improved performance of Tectona grandis seeds with gamma irradiation. Acta Hortic. 215: 51-53.

[10] Chiapuso G, Sanchez A M , Reigosa M J , Gonzalez L and Pellissier $F(1997)$ Do germination indices adequately reflect allelochemical effects on the germination process. J. Chem. Ecol. 23: 2445-2453.

[11] Czabator FJ (1962) Germination value: an index combining speed and completeness of Pine seed germination. Forest Science. 8: 386-396.

[12] Duncan D B (1955) Multiple range and multiple F tests. Biometrics 11:1-42.

[13] Ferreira D F (2008) Estatística multivariada. 1. ed. Lavras, UFLA, 662p.

[14] Gunkel J E and Sparrow A H (1961) Ionizing radiations: Biochemical, physiological and morphological aspects of their effects on plants. Encyc Plant Phys. 16: 555-611.

[15] Iglesias-Andreu L G, Octavio-Aguilar $P$ and Bello-Bello J (2012)Current Importance and Potential use of Low Doses Of Gamma Radiation in Forest Species. In: Feriz Adrovic, editor."Gamma Radiation”. In Tech Publishing, 978-53.

[16] IkRam N, Dawar S, Abbas Z and Javed Z (2010). Effect of (60cobalt) gamma rays on growth and root rot diseases in mungbean (Vigna radiata 1.). Pakistan Journal of Botany. 42(3):2165-2170.

[17] International Seed Testing Association (ISTA) (1999) International rules for seed testing. Seed Sci. Technol. 27: 333.

[18] Khalil S J, Rehman S, Afridi K and Jan M T (1986) Damage induced by gamma irradiation in morphological and chemical characteristics of barley. Sarhad J. Agric. 2: 45-54.

[19] Khodary S E A and Moussa H R (2003) Influence of Gamma Radiation and/or Salinity Stress on Some Physiological Characteristics of Lupine Plants. Egyptian J. Biotechnology. 13: 29-36.
[20] Kim J H , Baek M H, Chung B Y, Wi S G and Kim J S (2004) Alterations in the photosynthetic pigments and antioxidant machineries of red pepper (Capsicum annuиm L.) Seedlings from gamma irradiated seeds. J. Plant Biology. 47: 314-321.

[21] Kim M Y, Soon J M, Kim J H, Kim I J, Lee H Y, Lee D S, Lee Y J, Byun J H, Kim J H, Kim J Y, Jeong S R, Kim J H and Moon S H (2012) Changes in the phenolic composition of citrus fruits and leaves prepared by gamma irradiation of bud sticks. Life Science Journal. 9(3):1281- 1285.

[22] Kiong A, Ling Pick A, Grace Lai S H and Harun A R (2008) Physiological responses of Orthosiphon stamineus plantlets to gamma irradiation. Am-Eurasian J. Sustain. Agric. 2 (2): 135-149.

[23] Kovacs E and Keresztes A (2002) Effect of gamma and UV-B/C radiation on plant cell. Micron. 33: 199210.

[24] Kumar A, Mishra M N (2004) Effect of gamma rays EMS and NMU on germination, seedling vigor, pollen viability and plant survival in M1 and M2 generations of okRa (Abelmoschus esculentus L. Moench). Adv Plant Sci. 17: 295-297.

[25] Kumagai J , Katoh H, Kumada T, Tano A, Tano S and Miyazakit T (2000) Strong resistance of Arabidopsis thaliana and Raphanus sativus seeds for ionizing radiation as studied by ESR, ENDOR, ESE spectroscopy and germination measurement: Effect of long-lived and super-long-lived radicals. Radiation Physics and Chemistry. 57: 75-83.

[26] Kuzin A M, Vagabova M E and Revin A F (1976) Molecular mechanisms of the stimulating action of ionizing radiation on seeds. 2. Activation of protein and high molecular RNA synthesis. Radiobiologiya. 16: 259-261.

[27] Luckey T (1980) Hormesis with Ionizing Radiations. CRC press, Boca Raton, FLO, USA.

[28] Luckey T (1998) Radiation Hormesis: Biopositive Effect of Radiation. Radiation Science and Health. CRC press, Boca Raton, FLO, USA.

[29] Luckey T (2003) Radiation for health. Radio Prot. Manag. 20: 13-21.

[30] Mackay W A, Davis T D and D Sankhla (1995) Influence of scarification and temperature treatments on seed germination of Lupinus havardii. Seed Science \& Technology. 23: 815-821.

[31] Melki M and Marouani A (2010) Effects of gamma rays irradiation on seed germination and growth of hard wheat. Environ Chem Lett. 8(4):307-310

[32] Minisi F A, El-mahrouk M E, Rida M E F and Nasr M N (2013) Effects of Gamma Radiation on Germination, Growth Characteristics and Morphological Variations of Moluccella laevis L. American-Eurasian J. Agric. \& Enciron. Sci. 13 (5): 696-704.

[33] Nargis S, Gunasekaran M, Lakshmi S and Selvakumar P (1998) Effect of gamma irradiation on seed germination and vigor of tomato (Lycopersicon esculentum Mill). Orissa J Hortic. 26: 47-9.

[34] Preussa S B, Britta A B (2003) A DNA-damageinduced cell cycle checkpoing in Arabidopsis. Genetics. 164: 323-334.

[35] Sax K (1942) The mechanism of X-ray effects on cells. J. Gen. Physiol. 25, 533e537. 


\section{International Journal of Science and Research (IJSR) \\ ISSN (Online): 2319-7064 \\ Index Copernicus Value (2015): 78.96 | Impact Factor (2015): 6.391}

[36] Selvaraju P, Raja K (2001) Effect of gamma irradiation of seeds on germination of different tree species. In: IUFRO Joint Symposium on Tree Seed Technology, Physiology and Tropical Silviculture, College. Laguna, Philippines.

[37] Sharif A, Khan M R and Hussain S A (2000) Effect of gamma radiation on certain characters of Gossypium hirsutum L. Pak. J. Agric. Res. 16(2): 114-119.

[38] Sharafi Y and Azar A M (2011) Gamma irradiation influences on some biological traits in two almond (Prunus amygdalus, L) cultivars. Journal of Medicinal Plants Research. 5(2): 255-258.

[39] Shah T M, Atta B M, Haq M A and Mirza J I (2012) Radio-sensitivity of various Chickpea genotypes in M1 generation II-field studies. Pak. J. Bot., 44(2), 631-634.

[40] Singh S S and Vandana (2008) Sensitivity of Albizia julibrissin Durazz. Seeds to Gamma Rays. In proceeding of the FORTROP II: Tropical Forestry Change in a Changing World, 17-20 November 2008, Kasetsart University, Bangkok, Thailand. 25-39.

[41] Sing, S S and Sujata (2004) Effect of gamma rays on seed germination and seedling growth of Robinia pseudoacacia. Ind. J. Agrofor. 6(1): 33-38.

[42] Sjodin J (1962) Some Observations in X1 and X2 of Vicia faba L. after treatment with different mutagenes. Hereditas. 48:565-86.

[43] Sparrow A H (1960) Uses of large sources of ionizing radiation in botanical research and some possible practical applications. In Large Radiation Sources in Industry, 2: 195- 219 Intern. Atomic Energy Agency, Vienna..

[44] Sparrow A H, and Woodwell G M (1962) Pre- diction of the sensitivity of plants to chronic gamma irradiation. Radiation Botany. 2: 9- 26.

[45] Sparrow A H, Schwemmer, Susan S, Klug E E , Puglielli, Leanne (1970) Radiosensitivity studies with woody plants: II. Survival data for 13 species irradiated chronically for up to 8 years. Radiat. Res. 44 (1): 154-177.

[46] Stoeva N, Zlatev Z and Bineva Z(2001) Effect of Tidiazuron and diethilentriamine on gamma-irradiated oats and triticale plants. Journal of environmental protection and ecology. 2: 304-308.

[47] Thapa C B (2004) Effect of Acute Exposure of Gamma Rays on Seed Germination and Seedling Growth of Pinus kesiya Gord and P. wallichiana. A.B.Jacks. Our Nature. 2: 13-17.

[48] Wi S G, Chung B Y, Kim J H, Baek M H, Yang D H , Lee J W and Kim J S (2005), Ultrastructural changes of cell organelles in Arabidopsis stem after gamma irradiation. J. Plant Biol, 48(2): 195-200.

[49] Wi S G, Chung B Y, Kim J S, Kim J H, Baek M H, Lee J W and Kim Y S (2007) Effects of gamma irradiation on morphological changes and biological responses in plants. Micron. 38: 553-64.

[50] Zhang S , Cai Z and Wang X (2009) The primary signaling outputs of brassinosteroids are regulated by abscisic acid signaling. Proc Nat Acad Sci U.S.A.1106, 4543-4548.

Volume 6 Issue 1, January 2017 www.ijsr.net 